\title{
INTERACTIONS BETWEEN VERB MOVEMENT AND AGREEMENT IN KARITIANA(TUPI STOCK)
}

Luciana R. Storto

\section{Introduction}

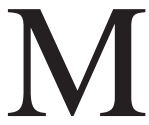

$\mathrm{y}$ goal is to show that Karitiana, an indigenous language spoken in Rondônia, Brazil, is a verb-final language that displays obligatory verb movement to $\mathrm{C}$ in root clauses. Evidence for verb raising to $\mathrm{C}$ comes from three sources: (i) the relative word order of the verb with respect to its arguments; (ii) agreement and tense; (iii) adverb adjunction. In subordinate clauses the verb stays in situ or adjoins to the subordinating head, an aspectual head which projects to the right of its VP complement.

Section 1 establishes that there is a complementary distribution between matrix and embedded clauses with respect to the position of the verb. The former are either verb-initial (VOS, VSO) or verb-second (SVO, OVS), whereas the latter are invariably verb-final (OSV, SOV). Verb raising in root clauses is associated with the presence of agreement and tense, which are absent in dependent clauses. This obligatory movement of the finite verb in root clauses,

* PROFIX Fellow (CNPq) at Museu de Arqueologia e Etnologia (MAE/USP). Professor of Descriptive Linguistics at Departamento de Lingüística (FFLCH/USP). 
bears a strong resemblance to the phenomenon known as verb-second (V-2) in Germanic languages (Den Besten, 1977; Koopman, 1983; Vikner 1995). We will see, however, that verb second in Karitiana has different properties than it has in Germanic. Specifically, Karitiana allows verb-initial clauses (although there is a tendency for the first position to be filled) and embedded clauses to not project TPs or CPs but rather are VPs dominated by a single functional projection: an aspectual phrase.

In section 2, I show that the specifier of the position to which the verb raises is a focus position. It is the landing site of wh-phrases, and focused phrases given as answers to wh-questions.

Section 3 is a discussion of clause structure motivated by evidence from adverb adjunction. We will see that most dependent clauses have one position for adverb adjunction (clause-initially), whereas SVO root clauses have three: before the subject, between the verb and the object, and after the object. I argue that this follows from the fact that verb movement to a second structural position takes place in root clauses, but not in dependent clauses. The impossibility of adverb adjunction between the subject and verb in matrix environments is explained by the fact that they are in the spec and head positions of $\mathrm{CP}$, respectively.

Although much work remains to be done in order to explain topic and focus effects in Karitiana matrix clauses, the difference between V-2 and V-1 word orders seems to correlate with the presence and absence, respectively, of a syntactically focused phrase in Spec, $\mathrm{CP}$, as well as with a phonological requirement to fill that position whenever possible.

This paper is composed of excerpts of my Ph.D. dissertation (Storto, 1999), selected and ordered with the goal of presenting the main hypotheses and corroborating data bearing on the phenomenon of verb raising in the language. 


\section{Verb raising}

There is complementary distribution between matrix and embedded clauses with respect to the position of the verb. In embedded clauses, the verb occurs in final position, whereas in matrix clauses it is either in first or second position: ${ }^{1}$

Transitive main clauses with agreement:

(1) Taso i-oky-t boroja "The man killed the snake" (non-decl) man 3-kill-nfut snake

(2) Taso Ø-na-oky-t boroja "The man killed the snake" (decl) man 3-decl-kill-nfut snake

Transitive main clause without agreement:

$\begin{array}{cll}\text { (3) *Taso } & \text { oky }(-t) & \text { boroja } \\ \text { man } & \text { kill(-nfut) } & \text { snake }\end{array}$

The examples above show that in transitive root clauses (declarative and non-declarative) the verb is in second position and agreement is obligatory. No agreement occurs in subordinate clauses, where the verb is in final position with respect to its arguments (cf (4)-(5)): ${ }^{2}$

1 Abbreviations: decl - declarative mood; nfut - non future tense; fut - future tense; perfve - perfective subordinator; impfve - imperfective subordinator; part - participle; cop - copula; det - determiner; aux - auxiliary; aux moving - auxiliary expressing movement of subject; aux sitting - auxiliary expressing sitting position of subject; det - determiner; 3 anaph $-3^{\text {rd }}$ person anaphoric pronoun; passiv - passive; OFC - object focus construction; obl - oblique case; caus - causative; assert - assertative mood; dir.evid - direct evidential; emph - emphatic.

2 The aspectual head following the verb takes VP as a complement. These headfinal aspectual projections (AspPs) are the only functional categories present in dependent clauses. AspPs are right-headed, in accordance with the head-final character of the language. 
Transitive embedded clauses without agreement:

(4) $[$ Boroja taso oky tykiri] $\emptyset$-naka-hyryp- $\varnothing$ õwã snake man kill perfve 3-decl-cry-nfut. child "When the man killed the snake, the child cried" (colloquial)

(5) [Taso boroja oky tykiri] $\varnothing$-naka-hyryp- $\varnothing$ õwã man snake kill perfve 3-decl-cry-nfut. child "When the man killed the snake, the child cried" (archaic)

Examples (4) and (5) are well-formed because in both cases the verb is final with respect to its arguments. The difference between the two clauses reflects a stylistic variation: OSV is the usual word order in a dependent clause (colloquial), whereas SOV is found in mythological narratives exclusively (archaic). The presence of third person agreement in (6) and (7) renders these sentences ungrammatical even when the word-order is verb-final:

Transitive embedded clauses with agreement:

$\begin{array}{clllll}\text { (6) *[Boroja } & \text { taso } & \text { i-oky } & \text { tykiri] } & \varnothing \text {-naka-hyryp- } \varnothing & \text { õwã } \\ \text { snake } & \text { man } & \text { 3-kill } & \text { perfve } & \text { 3-decl-cry-nfut. } & \text { child } \\ \text { (7) *[Taso } & \text { boroja } & \text { i-oky } & \text { tykiri] } & \varnothing \text {-naka-hyryp- } \varnothing & \text { ôwã } \\ \text { man } & \text { snake } & \text { 3-kill } & \text { perfve } & \text { 3-decl-cry-nfut. } & \text { child }\end{array}$

A change in word order resulting in verb-initial (cf. (8) and (9)) or verbmedial sentences (cf. (10) and (11)) is ungrammatical, whether or not agreement is present:

Transitive embedded clauses with or without agreement:

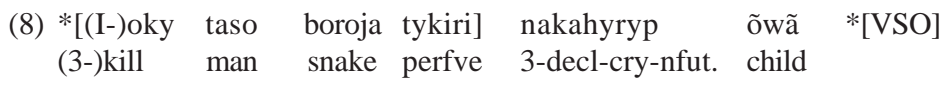




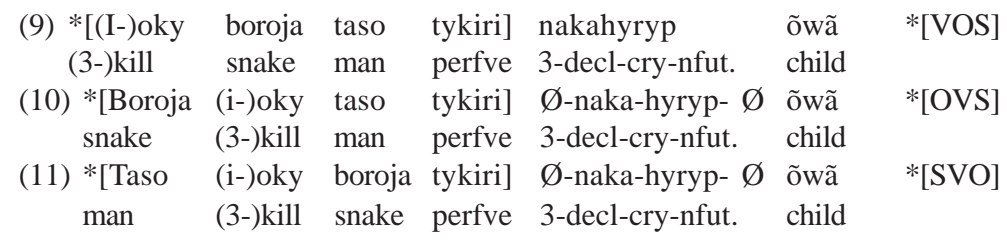

Intransitive clauses pattern in the same way as transitives: agreement is obligatory in root clauses (cf. (12) and (13)), where the verb is not in final position (Storto, 1997):

Intransitive main clause with agreement:
(12) Y-ta-opiso-t 1s-decl-listen-nfut
(yn)

Intransitive main clause without agreement:
(13) *Ta-opiso-t decl-listen-nfut

Examples (14) and (15) show that agreement does not occur in embedded clauses, where the verb is final ${ }^{3}$ (Storto, 1997):

3 The pronoun in (14) can cliticize to the verb, yielding (1) below. We know that the cliticized pronoun in (1) is not agreement, because it cannot co-occur with a pronoun (cf. (2)):
1. [Y-opiso] a-taka-kãrã-t an 1s-listen 2-decl-think-nfut 2s
2. *[Yn y-opiso] a-taka-kãrã-t an 1s 1s-listen 2-decl-think-nfut 2s 
Intransitive embedded clause without agreement:

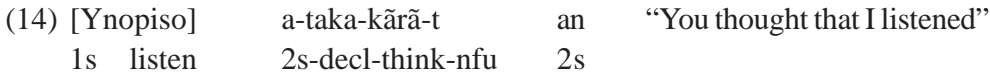

Intransitive embedded clause with agreement:

$\begin{array}{lll}\text { (15) *[Y-opiso yn] } & \text { a-taka-kãrã-t } & \text { an } \\ \text { 1s-listen } & \text { 1s 2-decl-think-nfut } & 2 \mathrm{~s}\end{array}$

Note that subordinate clauses lack tense morphology, in contrast to root clauses, where tense morphology is obligatory. In the examples above, the marker of nonfuture tense is -t after vowel-final roots, and $-\varnothing$ after consonant-final roots. This is evidence that, if the embedded verb raises at all, it raises to a functional head lower than $\mathrm{T}$ or to a tenseless $\mathrm{T}$, because embedded verbs never raise to a position in which tense is checked.

The complementary distribution observed can be explained if we assume that Karitiana is a verb-final language which displays obligatory verb movement in matrix clauses. When the verb moves, it checks tense and agreement. For this reason, verb-first or verb-second clauses have tense and agreement, whereas verb-final clauses do not. The latter have the verb either in situ, or adjoined to a head-final functional head that functions as a subordinator.

The hypothesis that the basic word order in Karitiana is verb-final makes sense both synchronically and diachronically. Synchronic evidence can be found in the head-final property of the language:

(i) PPs are right-headed:

(16) Ambyyk a-taka-karama-j ahe kyn Casa do Indio pi-p Then 2s-decl-turn-fut right toward Casa do Indio place-to/in

"Then you will turn right to (go to) Casa do Indio" 
(17) Sete de Setembro tyym a-taka-tar-i hotel pi-p

Sete de Setembro through 2s-decl-go-futhotel place-to/in

"You will get to the hotel through Sete de Setembro (avenue)"

(18) Ynna-amy-t kombo sepa pi-p

1s decl-put-nfut cocoa basket place-to/in

"I put the cocoa (fruit) in the basket"

(19) Koro'op pasap pitat taso op'it jonso hãrã sogng

Inside smooth very man young woman beautiful benefactive "The young man is in love with the beautiful woman"

(20) Iij na-aka-t i-mboryt "epe-"opo tyym

Bird decl-cop-nfut part-leave tree-hole through

"The bird left through the hole"

(21) Iij na-aka-t i-mboryt "epe-"opo pi-ri

Bird decl-cop-nfut part-leave tree-hole place-from

"The bird left from the hole"

(22) I-tyt y-taka-tar-i i-ambi-p

3-with 1s-decl-go-fut 3-house-to/in

"I will go to his house with him"

(ii) DPs, such as phrases headed by demonstratives are right-headed:

$\begin{array}{lllll}\text { (23) Ka } & \text { "irip } & \text { aka } & & \text { "That tapir (moving)" } \\ \text { Aux. } & \text { moving tapir } & & \text { det. } & \\ \text { (24) Ony } & \text { "irip } & \text { aka } & & \text { "That tapir (default)" } \\ \text { Aux } & & \text { tapir } & \text { det. } & \\ \text { (25) Ja } & \text { "irip } & \text { aka } & & \text { "This tapir (sitting)" } \\ \text { Aux.sitting } & & \text { tapir } & \text { det. }\end{array}$

(iii) Subordinate clauses are right-headed. The VP is taken as a complement by a head-final aspectual projection:

Kiit: "punctual" (temporal concidence):

(26) [Yn i-soko'i] kiit] $\quad$ a-otam-am

1s 3-tie.up exactly.when 2s-arrive-?

"When I tied it up, you arrived (at the exact time)"

Takiit: 'before':

(27) [Ta-tat] takiit]] naka-tat Porto Velho ta-sombak

3anaph-go before 3-decl-go Porto Velho 3anaph-watch-nfut

"Before he left, (he) went to look at Porto Velho" 
Byyk: "after" (subsequent perfective):

(28) [Yn na-soko `i] byyk]] yn a-taka-hir-i 1s decl-tie.up after 1s 2-decl-give-fut

"After I tie it up, I will give it to you"

Diachronically, the verb-final hypothesis fits the pattern found in the genetically related Tupi languages. All Tupi languages are strictly OV, and SOV is the word order hypothesized for Proto-Tupi, the ancestor language.

\section{Spec, CP as a focus position}

Focused arguments typically occupy Spec,CP. This A-bar position is the landing site of all focused arguments in wh-questions, answers to wh-questions, clefts and object focus constructions:

(29) Ergative subject in focus position:

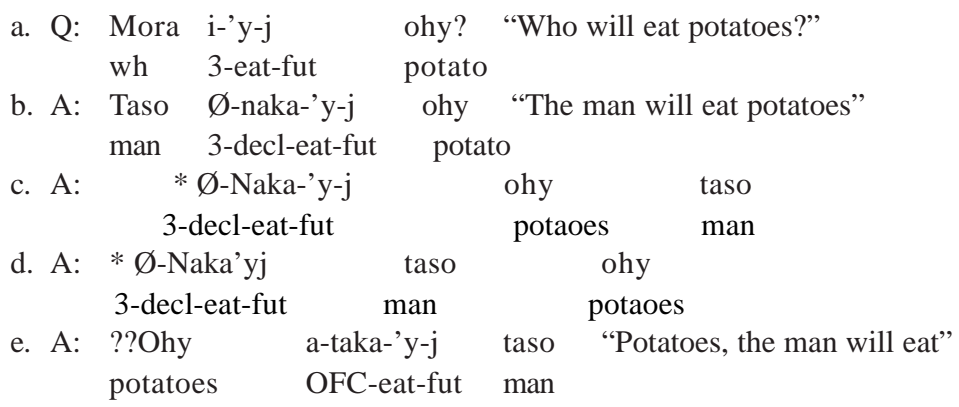

In (29) I show that the subject must be in preverbal position in answers to subject wh-questions. Verb-initial word orders (cf. (29c) and (29d)) or the 
declarative version of the object focus constructuion in (29e) cannot be used as answers in this case.

The declarative object focus construction in (30) is the ideal answer to an object wh-question. Note that the non-declarative version of the focus construction in (30f) is not a possible in this case because answers to whquestions must be declarative.

(30) Object in focus position:

a. Q: Mora-mon taso ti-'y-t-? "What did the man eat?" wh-copman OFC.part-eat-nfut

b. A: Ohy a-taka-'y-t taso "Potatoes, the man ate" potato passiv-decl-eat-nfut man

c. A: ?Taso naka-'y-t ohy "The man ate potatoes" man decl-eat-nfut potatoes

d. A: * Ø-Naka-'y-t ohy taso 3-decl-eat-nfut potatoes man

e. A: * Ø-Naka'yt taso ohy 3-decl-eat-nfut man potatoes

$\begin{array}{lll}\text { f. A. ??Ohy } & \text { i-ti-'y-t } & \text { taso } \\ \text { potatoes } & \text { 3-OFC-eat-nfut man }\end{array}$

Examples (31) and (32) show that focused time expressions and postpositional phrases must occur preverbally:

(31) Time expression in focus position:

a. Q: Tikat a-ama-j leite-ty? "When will you buy milk?" when 2s-buy-fut milk-obl

b. A: Dibm y-ta-ama-j leite-ty "I will buy milk tomorrow" tomorrow 1s-decl-buy-fut milk-obl

c. A: *Leite-ty dibm y-ta-amaj milk-obl tomorrow 1s-decl-buy-fut

d. A: *Y-ta-ama-j leite-ty dibm 1s-decl-buy-fut milk-obl tomorrow 
STORTO, L. R. Interactions between verb...
e. A: *Yta-ama-j
dibm
leite-ty
1s-decl-buy-fut
tomorrow
milk-obl
f. A: $*$ Dibm
leite-ty
ytaamaj
tomorrow milk-obl
1s-decl-buy-fut

(32) Postpositional phrases in focus position (Storto, 1997):
a. Q: Tihoop a-ama-j leite-ty? "Where will you buy milk?" where 2s-buy-fut milk-obl
b. A: Lider-pip y-ta-ama-j leite-ty "I will buy milk at the Lider" Lider-at 1s-decl-buy-fut milk-obl
c. A: *Leite-ty y-ta-ama-j Lider-pip milk-obl 1s-decl-buy-fut Lider-at
d. A: *Y-ta-ama-j leite-ty Lider-pip 1s-decl-buy-fut milk- obl Lider-at
e. A: *Y-ta-ama-j Lider-pip leite-ty 1s-decl-buy-fut Lider-at milk-obl
f. A: *Lider-pip leite-ty y-ta-ama-j
Lider-at milk-obl 1s-decl-buy-fut

To finalize this section, I will examine the two examples available in the corpus, which translate as multiple wh-questions in English but are not multiple questions in Karitiana. Although wh-phrases in-situ are not allowed in Karitiana, it is possible to use a third person pronoun in situ as a way to prime a pair-list answer:

(33) Oblique wh in Spec, CP, and third person pronoun in situ:
Q: Morã-pi-p
a-so'oot
i-ty-t?
Wh-place-in 2s-see(intr.)
3-obl-?
"Where did you see what?" (Where did you see "it"?)
A: Circo-pip y-ta-so'oot elefante-ty, zoologico-pip y-ta-so'oot girafa-ty Circus-place-in 1s-decl-see(intr.) elephant-obl zoo-place-in 1s-decl- ee giraffe-obl
At the circus I saw an elephant, at the zoo I saw a giraffe' 
The answer to the moved wh-phrase "where" is in Spec, CP in (33), as expected. However, a puzzle arises in (34). The way to ask "who killed what" is by moving the object wh-phrase to Spec, $\mathrm{CP}$ and leaving the subject pronoun in situ, although the answer has the subject in Spec, CP:

(34) Object wh in spec, $\mathrm{CP}$ and third person pronoun in situ:

Q: Mora-mon $\quad$ i ti-oky-t?
Wh-cop $\quad 3 \quad$ OFC-part-kill-nfut
"Who killed what?" (lit.: What did "he" kill?)
A: Jonso na-oky-t sojxa, taso na-oky-t "irip
Woman decl-kill-nfut pig man decl-kill-nfut tapir
"The woman killed the pig and the man killed the tapir"

Until further research is done on this topic, it is impossible to give an account of (34). For now, the issue must remain open.

\section{Adverb adjunction as evidence of verb raising in matrix clauses}

Adverbs in Karitiana left-adjoin to maximal projections. ${ }^{4} \mathrm{SVO}$ sentences allow three possible positions for adverb placement: before the subject, between

4 It is still unclear whether all adverbs have the same distribution in the language. At least the adverb slowly and the time expression at noon, which in English are restricted to VP and IP respectively, in Karitiana do not differ with respect to where they are allowed to occur. 
the verb and the object, or after the object, but crucially not between the subject and the verb, arguably because they are in a spec-head configuration: ${ }^{5}$

Matrix Clauses (Storto, 1997):

(35) Mynda taso na-m-potpora-jese Adv SVO
slowly man decl-caus-boil-fut
"The man boiled the water slowly"
(36) *Taso mynda na-m-potpora-jese
man slowly decl-caus-boil-fut water
"The man boiled the water slowly"
(37) Taso na-m-potpora-jmynda ese SV AdvO
man decl-caus-boil-fut slowly
"The man boiled the water slowly" water
(38) Taso na-m-potpora-jese mynda
man decl-caus-boil-fut water slowly
"The man boiled the water slowly"

5 The same pattern can be found with postpositional phrases:
1a. Y-'it naka-'a-t yn-ty
1s-father decl-say-nfut 1s-obl.
1b. Ynty naka'at y'it
1c. *Y'it ynty naka'at
1d. Naka'aty'it ynty
1e. Naka'at ynty y'it
2a. Paje na-kinda oti 'ap ejepo-ty "The shaman heals with stones"
shaman decl-thing_hurt_cure stone-obl
2b. Eyepoty nakinda oti 'ap paje
2c. *Paje ejepoty nakinda oti 'ap
2d. Nakinda oti 'ap paje ejepoty
2e. Nakinda oti 'ap ejepoty paje
3a. Luciananaka-hit boete-ty Claudiana
"Luciana gave the necklace to Claudiana"
"My father told us" decl-give necklace-obl.
3b. Luciana nakahit Claudiana boetety
3c. Boetety nakahit Luciana Claudiana
3d. *Luciana boetety nakahit Claudiana
3e. Nakahit Luciana Claudiana boetety
3f. Nakahit boetety Luciana Claudiana 
Contrast the pattern of adverb adjunction in matrix clauses with that of embedded clauses below. As seen before, with the exception of head internal relative clauses, dependent clauses have a single position for adverb adjunction; clause-initially (Storto, 1997):

Embedded Clauses:

(39) [mynda y-sypy-'et him okej)] AdvSOV slowly my-uncle meat cut "...that my uncle cut the meat slowly"

The adverb may not occur in non-initial position:

(40)*[ysypy'et mynda him okej]] *SAdvOV my-uncle slowly meat cut

(41)*[ysypy'et him mynda okej]] my-uncle meat slowly cut

(42)*[ysypy'et him okej) mynda] $\quad$ *SOV Adv my-uncle meat cut slowly

The difference between adverb adjunction in matrix and subordinate environments can be explained as a result of the fact that verb movement to a second position takes place exclusively in root clauses. When the verb moves, it raises high enough to make three maximal projections available for adverb adjunction. We will see that, if embedded verbs move at all, they adjoin to the head-final aspectual projection. Assuming there is no argument movement inside dependent clauses, an adverb will always surface clause-initially, independent of whether it left adjoins to VP or AspP. This is illustrated below: 
(43)

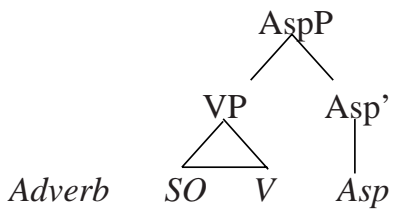

In my account, the embedded verb in (39) adjoins to the aspectual head position to the right of VP (in this case, a null head) without creating an extra position for adverb adjunction, since both VP and AspP are head-final. Evidence for this structure will be given when head-internal relative clauses are discussed.

Going back to the distribution of adverbs in matrix clauses, it is clear that intransitives show the same pattern discussed above for transitives: adverbs can surface before the verb in (44), between the verb and the subject in (48), and clause-finally (cf.(45)). Example (46) confirms what we saw in the transitive examples: that there is a prohibition against the occurrence of an adverb between the subject and the raised verb.

The word orders in (47) and (48) occur only in a very specific context: as echo comments to the sentence mynda nakatari taso (Adv VS). Echo comments can be defined as a speech practice in which the interlocutor repeats what was said by the speaker. In such contexts, the subject, verb and adverb are topics (old information) (Storto, 1997): ${ }^{6}$

(44) \$Omenda Ø-nakahyrỹj- ØGokyp Adv VS noon 3-decl-sing-nfut

Gokyp "Gokyp sang at noon"

(45) Gokyp $\quad$-naka-hyryj- $\varnothing \quad$ omenda $\quad$ SV Adv Gokyp 3-decl-sing-nfut noon

(46) * Gokyp omenda Ø-naka-hyrỹj- $\varnothing \quad$ *S Adv V Gokyp noon 3-decl-sing-nfut $\begin{array}{cll}\text { (47) ? } \varnothing \text {-nakahyryj- } \varnothing & \text { Gokyp } & \text { omenda?VS Adv } \\ \text { 3-decl-sing-nfut } & \text { Gokyp } & \text { noon }\end{array}$ Spec, CP is not filled by the subject (VS, VSO, VOS). 
$\begin{array}{cl}\text { (48) ? Ø-nakahyryj- } \varnothing & \text { omendaGokyp } \\ \text { 3-decl-sing-nfut } & \text { noon } \quad \text { Gokyp Adv S }\end{array}$

The intransitive embedded sentences below confirm what we saw in the transitive cases: that adverbs are limited to clause-initial position (cf.(49)):

(49) \$[Mynda yn opiso tykiri]...

[Adv SV Asp]

slowly $1 \mathrm{~s}$ hear perfve

"When I hear (something) slowly"

Adverbs occurring between the subject and the verb (cf. (50)), between the verb and an aspectual head (cf. (51)), or clause-finally (cf.(52)) are ungrammatical (Storto, 1997):

(50)*[Yn mynda opiso tykiri] ...

*[S Adv V Asp]

1s slowly hear perfve

(51)*[Yn opiso mynda tykiri]...

$1 \mathrm{~s}$ hear slowly perfve

(52)*[Yn opiso tykiri mynda]...

$1 \mathrm{~s}$ hear perfve slowly

*[SV Adv Asp]

*[SV Asp Adv]

The SVO sentences in (35)-(38) inform us about clause structure. The conclusions that can be drawn from the adverb adjunction facts are:

(i) The subject and the verb are in a spec-head configuration.

(ii) There is a maximal projection between the verb and the object.

(iii) Adverbs appearing after the object either left-adjoin to a maximal projection or right-adjoin to the clause. 
With respect to (i) above, we can safely say that the verb occupies the head of the maximal projection to which the subject moves because no adverb is allowed to intervene between S and V in SVO clauses. Both SAdvVO and SAdvV are strongly ungrammatical, as seen in (36) and (46), repeated below as (53)-(54), respectively:

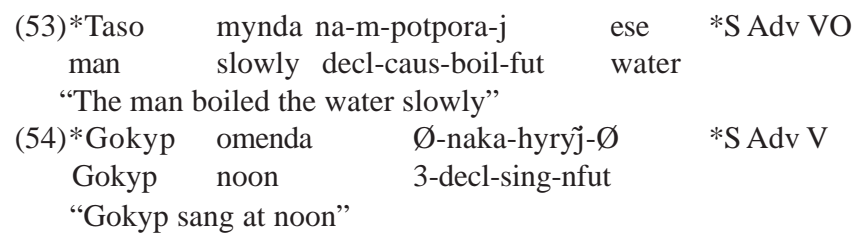

By now we have enough evidence to conclude that the subject occupies Spec, $\mathrm{CP}$ and the verb occupies $\mathrm{C}$ in SVO clauses. The head to which the verb raises is not I, because IP is head-final, and the landing site of the verb is the nuclear position of a head-initial projection. We saw in section 2 that the specifier of the maximal projection to which the verb raises is $\mathrm{Spec}, \mathrm{CP}$, and that phrases moved to that position are interpreted as focused: for instance, objects moving there for focus or wh-movement obligatorily trigger special focus morphology (ti-) on the verb. Since subjects in SVO sentences also move to a clause-initial position because they are focused (VOS order being used when the subject is a topic), it is likely that the highest maximal projection in SVO clauses is CP. Therefore, I conclude that clause-initial adverbs left-adjoin to the clause in SVO clauses.

We saw that the other position which adverbs may occupy in SVO sentences is beween the verb and the object (cf.(37)) This lead us to the conclusion in (ii): that there is a maximal projection between $\mathrm{V}$ and $\mathrm{O}$. The question we must now consider is where the adverb adjoins in sentences with SVAdvO word order. Assuming that $\mathrm{S}$ and $\mathrm{V}$ are in Spec, $\mathrm{CP}$ and $\mathrm{C}$ respectively, the object could be either in $\mathrm{Spec}, \mathrm{IP}^{7}$ or in situ when the word order is SVAdvO. Therefore,

7 As a strategy to understand the structure of Karitiana, I adopt a conservative theory of clause structure (Bittner; Hale, 1996a; 1996b), in which the only functional categories available are $\mathrm{C}$ and $\mathrm{I}$ : this allows as few positions as possible for movement. 
even with our constrained theoretical assumptions, there are two possible positions the object could be occupying in SVO clauses: Spec, IP or the base VP internal position:

(55) Object in Spec,IP

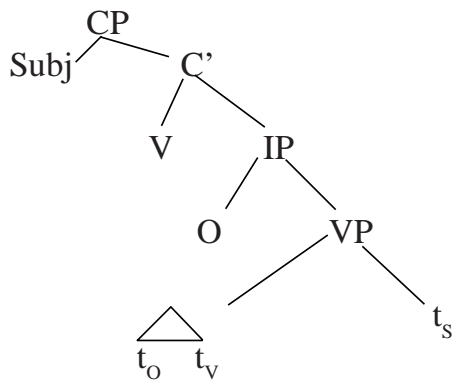

(56) Object internal to VP

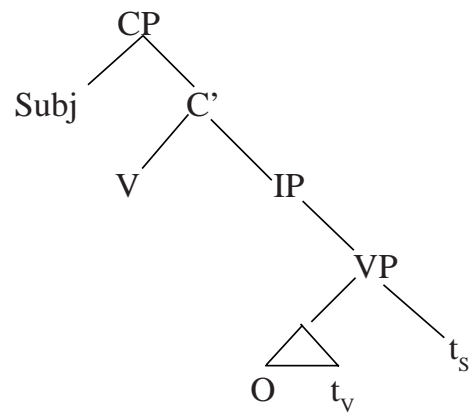

If the object is in Spec, IP (cf. (55)), the adverb in SVAdvO sentences is adjoined to IP and that in SVOAdv sentences is adjoined to VP. Conversely, if the object is internal to VP (cf. (56)), the adverb could be either adjoined to IP or to VP in SVAdvO sentences, and we would be forced to say that when the word order is SVOAdv the adverb is right adjoined to the clause. To choose between 
the two analyses represented in (55) and (56), it is important to consider whether or not Case licensing in Karitiana forces the object to raise to Spec, IP, as objects arguably do in some ergative languages. It makes perfect sense to hypothesize that the absolutive argument (object and intransitive subject) has to raise for Case reasons in Karitiana, because many ergative languages display that pattern of movement (the ones called "raising ergative" by Bittner and Hale (1996a; 1996b), and "syntactically ergative" by Dixon (1987; 1994). This is the hypothesis I suggested in previous work to account for word-order variation in Karitiana (Storto 1997; 1998). However, we will see that this hypothesis makes the wrong predictions with respect to the pattern of eccentric agreement present in object focus constructions, and for that reason it must be rejected. Another reason to reject this view of Case licensing is its needless complexity when compared with the alternative view: that arguments are licensed in situ (as it is the case in "transparent" ergative languages). We will see that there is plenty of evidence that Karitiana patterns with transparent ergative languages. For these reasons, I will assume that (56) is the correct surface structure for SVO clauses.

The only unpleasant result of assuming the structure in (56) as a representation of SVO clauses is that it forces us to say that a clause-final adverb is right-adjoined to CP. Note, however, that if we limit right-adjunction to the clause $(\mathrm{CP})$, our theory gains explanatory power, because:

(i) CPs do not project in subordinate clauses, which explains why there is no possibility of right-adjunction in dependent environments.

(ii) $\mathrm{CP}$, being the highest phrase, is the only maximal projection in which one would expect freedom of adjunction. Cross-linguistically, clauseinitial and clause-final positions have special pragmatic status (Ken Hale, p.c.) Furthermore, some Tupi languages allow adjunction of "extra" material such as adverbs and PPs to pre or post-clausal position (cf. Moore, 1994).

(iii) The fact that the language does not distinguish between VP and IP adverbs may follow from the fact that there is no difference between IP and VP adjunction of adverbs in the SVAdv $\mathrm{O}$ word order.

In fact, the hypothesis that adverbs may right adjoin to matrix CPs can be corroborated by head-internal relative clauses. 
We must now examine head internal relative clauses and explain how they differ from other subordinates, allowing two sites for adverb adjunction. The internal head of the relative clause raises above VP, presumably to Spec, AspP. Once the argument raises, two positions become available for adverb adjunction: AspP and VP(Storto, 1997):

(57) [OAdv SV]: adverb adjunction to VP

$\begin{array}{llllll}\text { Y-py-so'oot-on } & \text { yn } & \text { [sosy } & \text { mynda } & \text { ajxa } & \text { ti-oky]-ty } \\ \text { 1s-assert-nfut } & 1 \mathrm{~s} & \text { armadillo } & \text { slowly } & 2 \mathrm{p} & \text { OFC-kill-obl }\end{array}$

"I saw you (pl.) kill the armadillo slowly"

"I saw the armadillo you killed slowly"

(58) Adv [OSV]: adverb adjunction to AspP or adverb constructed with the matrix

Y-py-so'oot-on yn mynda [sosy
1s-assert-nfut ajxa $\quad 1 \mathrm{~s} \quad$ ti-oky]-ty
"I saw you (pl.) kill the armadillo slowly"
"I saw the armadillo you killed slowly"
or
"I gradually saw you (pl.) kill the armadillo"
"I gradually saw the armadillo you killed"

In (57) the internal head of the relative (the object sosy) raises to Spec, AspP, and the adverb is adjoined to VP. The utterance in (58) is ambiguous between a structure in which the adverb is part of the matrix (VSAdv [OSV]) and one in which it is part of the relative, adjoined to AspP (VS [Adv OSV]). This can be confirmed when we compare (58) and (59). In the latter the adverb is clearly part of the matrix clause (Storto, 1997):

$$
\begin{aligned}
& \text { (59)Y-py-so'oot-on yn [sosy ajxa ti-oky]-ty mynda } \\
& \text { 1s-assert-nfut } 1 \mathrm{~s} \quad \text { armadillo } \quad 2 \mathrm{p} \quad \text { OFC-kill-obl slowly } \\
& \text { "I gradually saw you (pl.) kill the armadillo" } \\
& \text { "I gradually saw the armadillo you killed" }
\end{aligned}
$$


The data in (57)-(61) constitutes conclusive evidence that right adjunction of adverbs to maximal projections other than the matrix CP is not an option in Karitiana. If that possibility were open, we would expect to find the word orders OSAdvV and OSVAdv in object head internal relative clauses, which are unattested (cf.(60)-(61)). Right adjunction of an adverb to the embedded VP, as in (60) or to AspP in (61) is ungrammatical (Storto, 1997):

$\begin{array}{cclll}(60) * \text { Y-py-so'oot-on } & \text { yn } & \text { [sosy } & \text { ajxa } & \text { mynda ti-oky]-ty } \\ \text { 1s-assert-nfut } & \text { 1s } & \text { armadillo } & 2 \mathrm{p} & \text { slowly OFC-kill-obl } \\ (61) * \text { Y-py-so'oot-on } & \text { yn } & \text { [sosy } & \text { ajxa } & \text { ti-oky mynda]-ty } \\ \text { 1s-assert-nfut } & \text { 1s } & \text { armadillo } & 2 \mathrm{p} & \text { OFC-kill slowly-obl }\end{array}$

We know (57)-(61) are head internal relative clauses because if the object sosy were outside the relative we would expect it to be suffixed by the oblique marker $-\mathrm{t}(\mathrm{y})$, which marks complements of the verb so'oot.

A head external relative clause is shown, for comparative purposes, in (62). The verb ohit, as the verb so'oot in (57), marks its objects with oblique Case. In the head external relative clause (62) both the external head of the relative and the relative itself are marked oblique, whereas in (57) the relative clause alone is marked oblique (Storto, 1998):

(62) Y-pyr-ohit-in $\quad$ yn 'ip-ity $\quad$ [an ti-'y]-t
1s-assert-fish-nfut 1s fish-obl2s
"I caught the fish for you to eat"

The structural difference between head internal and head external relative clauses is that in the former the head of the relative raises overtly to Spec, AspP, whereas in head external relatives the head is outside of the relative, coindexed with an empty operator which is internal to the relative, and moves from its base position to Spec, AspP. 
Recall that we explained the difference between SOV and OSV in dependent environments as a stylistic variation (archaic versus colloquial, respectively). Head internal relative clauses are the only environments in which this stylistic change in word order does not apply. In these types of relatives the difference is syntactic (the internal head of the relative raises to Spec,AspP). The strongest evidence for overt syntactic movement of the internal head is the presence of the obligatory object focus prefix $t i$ - on the verb in (63) and not in (64) (Storto, 1997):

\begin{tabular}{|c|c|c|}
\hline (63) Yn na-aka-t & i-so'oot- $\varnothing$ & [õwã [taso ti-mi]]-ty \\
\hline afut & 3 ps-see(intr)-nfut & [child [man OFC-hit]]-obl. \\
\hline "I saw [the child $\mathrm{v}$ & ho the man hurt/th & ild be hurt by the man]" \\
\hline (64) Yn na-aka-t & i-so'oot- $\varnothing$ & [õwã mi]-ty \\
\hline $1 \mathrm{p}$ decl-aux-nfut & $3 p$-see-nfut & child hit]-obl. \\
\hline
\end{tabular}

Having argued for an underlying OVS word-order with obligatory raising of the embedded verb to Asp, I now conclude this section with a note about the position of aspectual auxiliaries. A point that must be made about the complementary distribution in word order between subordinate and root clauses is the fact that the base position of aspectual auxiliaries must be the same in both environments. This is a generalization based on empirical grounds: the aspectual morphology found in embedded clauses (for instance, the imperfective tysyp) is also present in root clauses:
(65) [I-soko'i y-tat tysyp-y'oot] a-taka-mew-i 3-tie.up 1s-go impfve.aux.-inceptive 2s-decl-arrive-fut "When I am going to tie it up, you will arrive"
(66) [I-hadna sogng] myrỹ'in ytakatat tysyp, y-taka-'a ta'ãt yn-o 3 -speak since only 1s-decl-go impfve.aux 1s-decl-say direvid1s-emph "Since he spoke with me, I am goind there, I said"


The matrix verb and aspectual auxiliary form a complex head that occupies second position. In dependent environments, aspectual heads are clause-final. If they are generated in this final position, then they must have raised and adjoined to the verb when it is in second position. This suggests that the second structural position to which the verb raises is not $\mathrm{T}$, because $\mathrm{T}$ must be the premovement position of the auxiliary. The conclusion I draw from the data in (65)(66) is that the landing site of the main verb is not $\mathrm{T}$.

\title{
RESUMO
}

Este artigo tem como objetivo mostrar que o Karitiana, uma língua da família Arikém, tronco Tupi, falada em Rondônia, Brasil, é uma língua V-2, que apresenta movimento obrigatório do verbo para a posição de complementizador (C) nas sentenças matrizes. $\mathrm{O}$ verbo transitivo, invariavelmente, ocorre em primeira ou segunda posição em relação a seus argumentos nas sentenças principais, quando aparece, obrigatoriamente, marcado por tempo e concordância. Já nas sentenças subordinadas, o verbo aparece nú na última posição. Apresentamos evidências de movimento verbal ao discutirmos a ordem dos constituintes, a posição dos núcleos funcionais nas sentenças, e as possibilidades de adjunção adverbial na língua.

Palavras-chave: Tupi, Karitiana, V-2, posicionamento adverbial.

\begin{abstract}
This paper aims to show that Karitiana, a language of the Arikém family, Tupi stock, spoken in Rondônia, Brazil, is a verb-second language, which presents obligatory movement of the verb to complementizer position (C) in root clauses. The transitive verb, invariably, occurs in first or second position with respect to its arguments in matrix clauses, when it is marked by tense and agreement morphology. In embedded clauses, the verb is bare and occurs in final position. We present evidence of verb movement through a discussion of constituent order, the position of functional heads in the sentence, and adverb adjunction possibilities.

Key-words: Tupi, Karitiana, Verb second, Adverb placement.
\end{abstract}


STORTO, L. R. Interactions between verb...

\section{REFERENCES}

BITTNER, M.; HALE, K. The Structural Determination of Case and Agreement. Linguistic Inquiry, n. 27, p. 1-68, 1996a.

. Ergativity: toward a theory of a heterogeneous class. Linguistic Inquiry, v. 4, n. 27 p. 531-604, 1996b.

DEN BESTEN, H. On the Interaction of Root Transformations and Lexical Deletive Rules. Ms. University of Amsterdam. Published 1981 in Groninger Arbeitern zur Germanistischen Linguistik 20, p. 1-74; republished 1983 in WERNER, A. (Ed.)., on the Formal Syntax of Westgermania, John Benjamins, Amsterdam, p. 47-131; republished 1989 in Hans den Besten, Studies in West Germanic Syntax, Rodopi, Amsterdam, p. 44100, 1977. [C/ AUTOR: Manter todas as referências em que aparece o artigo? Se forem mantidas, separar cada uma delas]

DIXON, R. Studies in Ergativity. Amsterdam: Elsevier, 1987.

Ergativity. Cambridge Studies in Linguistics 69. Cambridge: Cambridge University Press, 1994.

KOOPMAN, H. The Syntax of Verbs. Studies in Generative Grammar. Dordrecht: Foris, 1983.

MOORE, D. A Few aspects of Comparative Tupi Syntax. $47^{\text {th }}$ International Congress of Americanists. Revista Latinoamericana de Estudios Etnolingüísticos, Lima, n. 8, 1994.

STORTO, L. Verb Raising and Word order variation in Karitiana. Boletim da Associação Brasileira de Lingüística (Abralin), n. 20, 1997.

Karitiana: A verb Second Language from Amazonia. In: CONFERENCE OF STUDENTS OF LINGUISTICS OF EUROPE (CONSOLE), 6., 1998, [LOCAL??]. Proceedings... [LOCAL: Editora??], 1998.

. Aspects of a Karitiana Grammar. Massachusetts, 1999. Ph.D. Dissertation Massachusetts Institute of Technology.

VIKNER, S. Verb Movement and Expletive Subject in the Germanic Languages. Oxford: Oxford University Press, 1995. 